\title{
Treatment of severe oral mucositis in a pediatric patient undergoing chemotherapy
}

\author{
Protocolo de tratamento da mucosite oral grave durante o tratamento quimioterápico em paciente pediá- \\ trico
}

Isabella Lima Arrais RIBEIRO'

Ana Maria Gondim VALENÇA'

Paulo Rogério Ferreti BONAN' ${ }^{1}$

\begin{abstract}
This article reports the resolution of a case of severe oral mucositis and the treatment protocol that promoted complete remission of the lesions. A male 13-year-old patient with chondroblastic osteosarcoma in the left distal thigh and acute lymphoblastic leukemia undergoing cancer treatment with methotrexate presented with severe oral mucositis. The treatment protocol included the use of $10 \mathrm{ml}$ of a mucositis mouthwash and low-level laser therapy. The lesions remitted after five days of gargling with the mucositis mouthwash and two sessions of low-level laser therapy on the lesions. The use of a treatment protocol consisting of a mucositis solution associated with low-level laser therapy effectively resolved a case of severe chemotherapy-induced oral mucositis. The monitoring and treatment of oral mucositis lesions in children and adolescents undergoing chemotherapy are necessary to prevent the patient from suffering from induced comorbidities.
\end{abstract}

Indexing terms: Chemotherapy. Lips. Neoplasms. Stomatitis.

\section{RESUMO}

Esse artigo relata a resolução de um caso de mucosite oral grave e do protocolo de tratamento utilizado para a completa remissão das lesões. Paciente do sexo masculino, 13 anos, portador de osteossarcoma condroblástico na coxa esquerda distal e leucemia linfoblástica aguda apresentou um quadro de mucosite oral grave, encontrando-se sob tratamento antineoplásico fazendo uso de metotrexato. Adotou-se um protocolo de tratamento que incluiu a utilização diária de bochecho com $10 \mathrm{ml}$ de uma solução para mucosite e a aplicação de laser de baixa potência. A remissão das lesões de deu após 5 dias de utilização dos bochechos com a solução para mucosite e 2 sessões de irradiação das lesões com laser. A adoção do protocolo de tratamento com uma solução para mucosite associada à aplicação de laser de baixa potência se mostrou efetiva na resolução da mucosite oral grave decorrente da terapêutica antineoplásica. Faz-se necessário o monitoramento e tratamento de lesões por mucosite oral em crianças e adolescentes sob tratamento oncológico com quimioterápicos, a fim de que os pacientes não venham a sofrer em decorrência das comorbidades que são geradas.

Termos de indexação: Quimioterapia. Lábio. Neoplasias. Estomatite.

\section{INTRODUCTION}

Chemotherapy-induced mucositis is one of the most important undesirable side effects of cancer treatment, promoting the worst cases of morbidity, increasing length of hospital stay, and frequently reducing the odds of controlling the tumor and the patient's life expectancy?.
Ulcers caused by oral mucositis can be an important source of systemic infection, especially in immunosuppressed patients ${ }^{2-3}$. Moreover, oral mucositis induces pediatric patients to reduce food intake, which affects their nutritional status and makes them less responsive to treatment ${ }^{4-5}$. Sonis et al. ${ }^{5}$ reported that $78 \%$ of chemotherapy patients presented with mucositis at some point during treatment.

\footnotetext{
${ }^{1}$ Universidade Federal da Paraíba, Programa de Pós-Graduação em Modelos de Decisão e Saúde, Departamento de Estatística. Cidade Universitária, s/n., 58051-900, João Pessoa, PB, Brasil. Correspondência para / Correspondence to: ILA RIBEIRO. E-mail: <isabella_arrais@yahoo.com>.
} 
This study aimed to report the resolution of a case of severe oral mucositis and demonstrate the intervention protocol used by the pediatric sector of the Hospital Napoleão Laureano (João Pessoa, PB) for treating these cases.

\section{CASE REPORT}

A brown 13-year-old boy with chondroblastic osteosarcoma in the left distal thigh and acute lymphoblastic leukemia presented with severe oral mucositis (Oral Assessment Guide / OAG) ${ }^{6}$, namely, ulcerated skin and mucosa in the upper and lower lips (Figure 1), and complaints of pain and much discomfort, especially when talking and eating. According to the medical record, the patient had been undergoing cancer treatment for one year and eight months. Before the mucositis lesions appeared, the patient had been given a treatment protocol that included methotrexate $(50 \mathrm{mg})$ at 8-day intervals. The lesions appeared 14 days after the last dose of methotrexate.

Blood tests showed the following numbers of red blood cells, leucocytes, and platelets, respectively, when the oral mucositis lesions were diagnosed and after their complete remission: $\left(2,700\right.$ million/ $\mathrm{mm}^{3} ; 300 ; 78,000 /$ $\left.\mathrm{mm}^{3}\right)$ and (3,360 million/ $\mathrm{mm}^{3} ; 38,600$ (after filgrastim); $\left.115,000 / \mathrm{mm}^{3}\right)$.

In face of the patient's condition, the option was to begin the treatment protocol for severe oral mucositis lesions used frequently by the pediatrics sector of the Hospital Napoleão Laureano (João Pessoa-PB). This protocol includes gargling four times a day with a mucositis mouthwash (Figure 2), which had the following composition: $0.9 \%$ saline $(250 \mathrm{ml})$, nystatin $(20 \mathrm{ml})$, dexamethasone $(2 \mathrm{mg} / \mathrm{ml} ; 1 \mathrm{ml}$ ampule), diphenhydramine (50mg/ml; $1 \mathrm{ml}$ ampule), morphine (10 mg/ml; $1 \mathrm{ml}$ ampule), $2 \%$ lidocaine $(10 \mathrm{ml})$, and vitamin B complex (1 ampule), prepared daily by the hospital and the use of low-level laser therapy (ECCO Fibras e Dispositivos/Brazil; n/s - 040401; model - BM0004A) calibrated for a wavelength of $670 \mathrm{~nm}$, power of $40 \mathrm{~mW}$, and dose of $4 \mathrm{~J} / \mathrm{cm}^{2}$, applied locally for 30 seconds on the reddened and ulcerated lip regions with or without pseudomembrane (Figure 3).

The lesions resolved after using the mucositis mouthwash for five days and undergoing two sessions of low-level laser therapy on two consecutive days, the first and second days after lesion onset. Seven days after the beginning of treatment the lesions had remitted completely, the labial skin and mucosa had healed, and the patient was again able to talk and eat without discomfort (Figure 4).

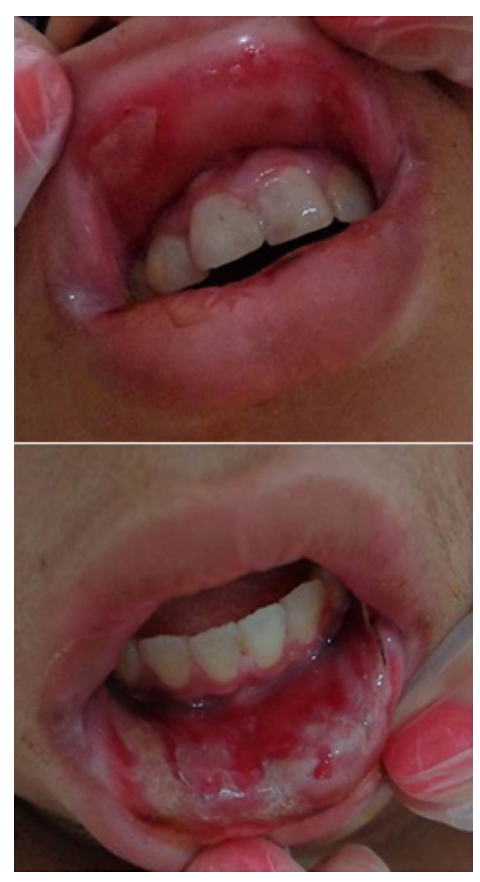

Figure 1. Severe oral mucositis lesions affecting the skin and mucosa of the upper and lower lips.

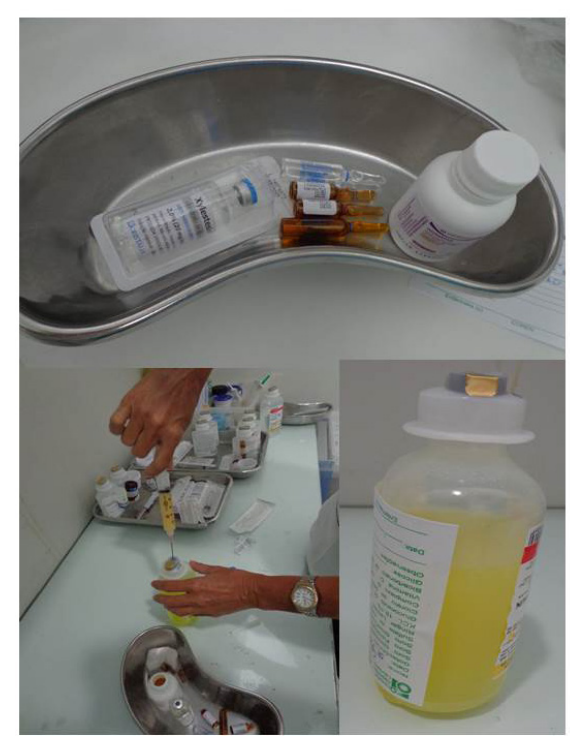

Figure 2. Mucositis solution.

Note: Which had the following composition: $0.9 \%$ saline $(250 \mathrm{ml})$, nystatin $(20 \mathrm{ml})$, dexamethasone $(2 \mathrm{mg} / \mathrm{ml} ; 1 \mathrm{ml}$ ampule), diphenhydramine $(50 \mathrm{mg} / \mathrm{ml} ; 1 \mathrm{ml}$ ampule), morphine $(10 \mathrm{mg} / \mathrm{ml} ; 1 \mathrm{ml}$ ampule), $2 \%$ lidocaine $(10 \mathrm{ml})$, and vitamin B complex (1 ampule). 


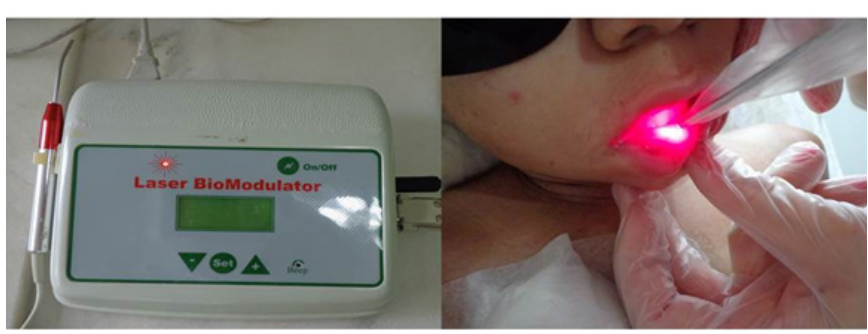

Figure 3. Lesion irradiation with low-level laser.

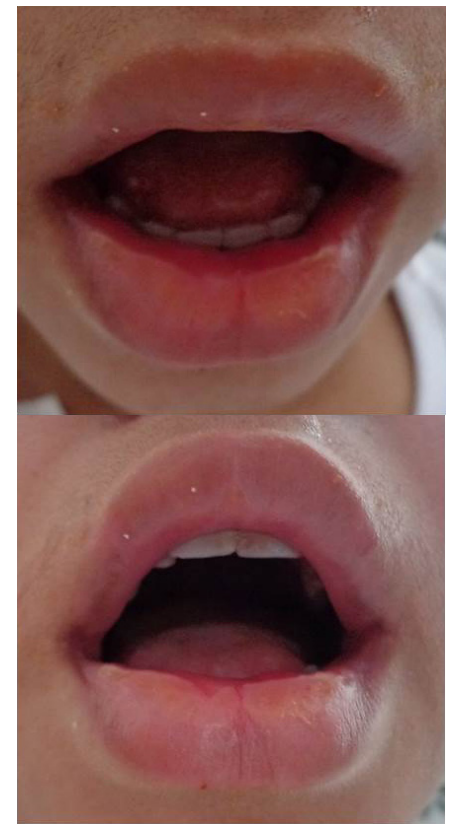

Figure 4. Healed upper and lower lips seven days after lesion onset.

\section{DISCUSSION}

Oral mucositis lesions, commonly present in pediatric cancer patients ${ }^{1,7-8}$, are associated with the type, dose, and administration frequency of anticancer agents ${ }^{9-10}$, and with factors such as neutropenia, which in general occurs about 15 days after anticancer drug admistration'; this length of time coincides with the presence of oral mucositis in children and adolescents ${ }^{9}$.

When the oral mucositis lesions of the study patient were diagnosed, he had severe leukopenia, presenting 300 leukocytes $/ \mathrm{mm}^{3}$ when the ideal number ranges from 6,000 to 8,000 . By the time the lesions had healed, the number of leukocytes had risen to $38,600 / \mathrm{mm}^{3}$ in response to filgrastim, a human granulocyte colony-stimulating factor that acts on the bone marrow to increase neutrophil production ${ }^{11}$. However, filgrastim is not associated with lower oral mucositis severity ${ }^{12-13}$. Moreover, the number of red blood cells and platelets increased between the two complete blood counts but remained below the ideal: 4,500-5,900 million/ $\mathrm{mm}^{3}$ for red blood cells and 150,000$450,000 / \mathrm{mm}^{3}$ for platelets.

The dentistry team of the pediatric sector of the hospital where the present case was registered and treated uses the Oral Assessment Guide modified by Cheng et al. ${ }^{6}$, an instrument that allows oral monitoring, ranging from saliva changes, which are the most common in chemotherapy patients ${ }^{14}$, to changes in the oral skin and mucosa, and palatal, buccal, and gingival mucosa. The instrument also verifies whether the patient is experiencing pain or inability to swallow and talk. Some of the instrument's options are "no change;" "mild mucositis," defined as the presence of inflammation and/or moderately compromised function; and "severe mucositis," defined as the presence of ulcers and fully compromised function. Therefore, it is possible to monitor oral inflammation and introduce treatment protocols according to the oral mucositis diagnosis.

Chemotherapeutic agents are not equally stomatotoxic. The most common drugs used for treating neoplasms in children and adolescents are: vincristine, paclitaxel, cytarabine, doxorubicin, 5-flurouracyl, cyclophosphamide, cisplatin, and methotrexate; the last four are most commonly associated with the development of changes in the oral mucosa ${ }^{15-16}$. Corroborating these findings, the study patient received one of the drugs most commonly associated with stomatotoxicity.

The hospitalization of children undergoing cancer treatment changes their daily routine, which alters their food habits, and generates treatment-related stress. Additionally, the greater attention directed by the medical and nurse teams to treating the diseases that led to the child's hospitalization may lead them to neglect oral health care ${ }^{17-18}$. Dental care is critical for promoting the health of pediatric cancer patients as it takes preventive and intervention actions that boost oral health conditions, favoring good nutrition and lowering the risk of infections of various natures ${ }^{19}$. Chemotherapy-related oral problems debilitate patients' general health status, making them less responsive to treatment, which lengthens hospital stay, and increasing morbidity and mortality, which are mainly associated with infections ${ }^{20}$.

Intervention protocols for chemotherapy-induced lesions can be used on pediatric patients. However, the lack of a universal protocol ${ }^{21}$ requires the medical and dental staff to share their experiences treating these 
lesions to improve the instituted protocols or to implement a treatment protocol for oral mucositis in institutions that need but do not have one.

The mucositis solution used herein must be prepared daily at the hospital because the pharmaceuticals lose their effect after 24 hours. The components include nystatin, an antifungal; dexamethasone, an antiinflammatory; diphenhydramine, an antihistamine; morphine, a potent analgesic; lidocaine, a local anesthetic; and vitamin B complex, an adjuvant of cell metabolism for tissue repair. These agents enable a patient to bear the lesion while it is not fully healed ${ }^{22}$, preventing the progression of the inflammatory response, tissue destruction ${ }^{23}$, and the development of opportunistic infections ${ }^{20}$.

The protocol with low-level laser therapy has been considered an effective treatment for oral mucositis ${ }^{24}$. Although there is no consensus on the optimal energy dose, the wavelength is usually $660 \mathrm{~nm}$ to $670 \mathrm{~nm}$, and the power, 40 to $60 \mathrm{~mW}^{21}$.

In addition to the treatment protocol for active lesions or when monitoring children/adolescents for mucositis, it is important to advise children/adolescents and/or the person responsible for their oral hygiene: to brush their teeth with a soft toothbrush, using gentle,

\section{REFERENCES}

1. Cheng KKF, Lee V, Li CH, Goggins W, Thompson DR, Yuen HL, et al. Incidence and risk factors of oral mucositis in paediatric and adolescent patients undergoing chemotherapy. Oral Oncol. 2011;47(3):153-62. doi: 10.1016/j.oraloncology.2010.11.019

2. Sonis ST. Mucositis as a biological process: a new hypothesis for the development of chemotherapy-induced stomatotoxicity. Oral Oconol. 1998;34(1):39-43. doi: 10.1016/S13688375(97)00053-5

3. Mathur VP, Dhillon JK, Kalra G. Oral health in children with Leukemia. Indian J Palliat Care. 2012;18(1):12-8. doi: 10.4103/0973-1075.97343

4. Green R, Horn H, Erickson JM. Eating Experiences of Children and Adolescents With Chemotherapy - Related Nausea and Mucositis. J Pediatr Oncol Nurs. 2010;27(4):209-16. doi: 10.1177/1043454209360779.

5. Sonis ST, Eilers JP, Epstein JB, Leveque FG, Ligget WH Jr, Mulaga MT, et al. Validation of a new scoring system for the assessment of clinical trial research of oral mucositis induced by radiation or chemotherapy. Cancer. 1999;85(10):2103-13. doi: $\quad 10.1002 /(\mathrm{SICI}) 1097-0142(19990515) 85: 10<2103:: A I D-$ CNCR2>3.0.CO;2-0

6. Cheng KK, Chang AM, Yuenc MP. Prevention of oral mucositis in paediatric patients treated with chemotherapy: a randomised circular motions, making the bristles traverse the teeth and gums; to brush their teeth after every time they eat; to carefully use dental floss or tape before bedtime; to gargle with an alcohol-free $0.12 \%$ chlorhexidine solution once a day; to drink water frequently; and to use a lip moisturizer.

\section{CONCLUSION}

The use of a treatment protocol consisting of daily gargling with a mucositis mouthwash and low-level laser therapy effectively resolved a case of severe chemotherapyinduced oral mucositis.

Routine monitoring of oral mucositis lesions in children and adolescents undergoing chemotherapy can prevent their suffering from chemotherapy-induced comorbidities, such as malnutrition and opportunistic infections, which may require chemotherapy interruption, reducing the chances of controlling cancer growth and consequently, of achieving cure.

\section{Collaborators}

ILA RIBEIRO, AMG VALENÇA, and PRF BONAN participated in all the stages of article development.

crossover trial comparing two protocols of oral care. Eur J Câncer. 2004;40(8):1208-16. doi:10.1016/j.ejca.2003.10.023

7. Hespanhol FL, Tinoco EMB, Teixeira HGC, Fallabela MEV, Assis NMSP. Manifestações bucais em pacientes submetidos à quimioterapia. Ciênc Saúde Coletiva. 2010;15(supl 1):1085-94. doi: 10.1590/S1413-81232010000700016

8. Javed F, Ultreja A, Bello Correa FO, Al-Askar M, Hudieb M, Qayyum $F$, et al. Oral health status in children with acute lymphoblastic leukemia. Crit Rev Oncol Hematol. 2012;83(3):303-9. doi: 10.1016/j.critrevonc.2011.11.003

9. Cheng KK, Goggins WB, Lee VWS, Thompson DR. Risk factors for oral mucositis in children undergoing chemotherapy: a matched case-control study. Oral Oncol. 2008;44(11):1019-25. doi: 10.1016/j.oraloncology.2008.01.003

10. Otmani N, Alami R, Soulaymani A, El Mokhtari A, Khattabi M. Sex, age and $A B O$ blood groups in chemotherapy-induced oropharyngeal mucositis. Minerva Stomatol. 2008;57(10):5059.

11. Ferreira P, Gamba MA, Saconato H, Gutiérrez MGR. Treatment of mucositis in patients undergoing bone marrow transplantation: a systematic review. Acta Paul Enferm. 2011; 24(4):563-70. doi: 10.1590/S0103-21002011000400018

12. Valcárcel D, Sanz MA Jr, Sureda A, Sala M, Muñoz L, Subirá M, et al. Mouth-washings with recombinant human granulocytemacrophage colony stimulating factor (rhGMCSF) do not improve grade III-IV oropharyngeal mucositis (OM) in patients 
with hematological malignancies undergoing stem cell transplantation. Results of a randomized double-blind placebocontrolled study. Bone Marrow Transplant. 2002;29(9):783-7. doi: $10.1038 / \mathrm{sj} / \mathrm{bmt} / 1703543$

13. Dazzi C, Cariello A, Giovanis P, Monti M, Vertogen B, Leoni $M$, et al. Prophylaxis with GM-CSF mouthwashes does not reduce frequency and duration of severe oral mucositis in patients with solid tumors undergoing highdose chemotherapy with autologous peripheral blood stem cell transplantation rescue: a double blind, randomized, placebo-controlled study. Ann Oncol. 2003;14(4):559-63. doi: 10.1093/annonc/mdg177

14. Pimenta Amaral TM, Campos CC, Moreira dos Santos TP, Leles $C R$, Teixeira AL, Teixeira MM, et al. Effect of salivary stimulation therapies on salivary flow and chemotherapy-induced mucositis: a preliminary study. Oral Surg Oral Med Oral Pathol Oral Radiol 2012;113(5): 628-37. doi: 10.1016/j.0000.2011.10.012

15. Sandoval RL, Koga DH, Buloto LS, Suzuki R, Dib LL. Management of chemo and radiotherapy induced oral mucositis with low-energy laser: initial results of A.C. Camargo Hospital. J Appl Oral Sci. 2003;11(4): 337-41. doi: 10.1590/S1678-77572003000400012

16. Santos TFR, Coradini CD, Ribeiro DM, Caldo-Teixeira AS. Knowledge and practice of oral health in child patients with cancer. Arq Odontol. 2010;46(1):5-10.

17. Cádiz VD, Urzúa AM, Campbell MB. Calidad de vida en niños y adolescentes sobrevivientes de leucemia linfoblástica aguda. Rev Chil Pediatr. 2011;82(2):113-21. doi: 10.4067/S037041062011000200005

18. Sung L, Yanofsky R, Klaassen RJ, Dix D, Pritchard S, Winick N, et al. Quality of life during active treatment for pediatric acute lymphoblastic leukemia. Int J Câncer. 2011;128(5):1213-20. doi: 10.1002/ijc.25433
19. Barbosa AM, Ribeiro DM, Caldo-Teixeira AS. Conhecimentos e práticas em saúde bucal com crianças hospitalizadas com câncer. Ciênc Saúde Coletiva. 2010;15(1):1113-22. doi: 10.1590/ S1413-81232010000700019

20. Skolin I, Wahlin YB, Broman DA, Koivisto Hursti U, Vikström Larssom M, Hemell O. Altered food intake and taste perception in children with cancer after start of chemotherapy: perspectives of children, parents and nurses. Support Care Cancer. 2006;14(4):369-78. doi: 10.1007/s00520-005-0904-6

21. Figueiredo ALP, Lins L, Cattony AC, Falcão AFP. Laser terapia no controle da mucosite oral: um estudo de metanálise. Rev Assoc Med Bras. 2013;59(5):467-74. doi: 10.1016/j.ramb.2013.08.003

22. Ribeiro Júnior O, Borba AM, Guimarães Júnior J. Prevention and treatment of oral mucositis: the fundamental role of dentist: review. Rev Clín Pesq Odontol. 2010;6(1):57-62.

23. Peres P, Queiroz AM, Moreira MR, Faquim JPS, Ferrari MACM. Pediatric dentistry applied to childhood cancer - clinical manifestations and protocol service. J Manag Prim Health Care. 2013;4(3):191-9.

24. Lima $A G$, Antequera $R$, Peres MP, Snitcosky IM, Federico $M H$, Villar RC. Efficacy of Low-Level Laser Therapy and Aluminum Hydroxide in Patients with Chemotherapy and RadiotherapyInduced Oral Mucositis. Braz Dent J. 2010;21(3):186-92. doi: 10.1590/S0103-64402010000300002

Received on: 6/5/2015

Final version resubmitted on: 15/6/2015

Approved on: 3/7/2015 